Chirurgia (2017) 112: 332-341

No. 3, May - June

Copyright@ Celsius

http://dx.doi.org/10.21614/chirurgia.112.3.332

\title{
GOOD TO KNOW: The ALPPS Procedure - Embracing a New Technique
}

\author{
George-Andrei Popescu, Sorin Tiberiu Alexandrescu, Razvan Tudor Grigorie, Luminița Stoica, \\ Cristian Alexandru Apavaloaie, Doina Hrehoreț
}

"Dan Setlacec" Center of General Surgery and Liver Transplantation, Fundeni Clinical Institute, Bucharest, Romania

Corresponding author:

Doina Hrehoret, MD, PhD

"Dan Setlacec" Center of General

Surgery and Liver Transplantation,

Fundeni Clinical

Soseaua Fundeni, 258, Sector 2,

Bucharest, 022328, Romania

E-mail: doinitahrehoret@yahoo.com

Abbreviations:

ALPPS - Associating Liver Partition and Portal vein ligation for Staged

hepatectomy

CRLM- Colorectal Liver Metastases

FLR - Future Liver Remnant

LAPS - Laparoscopic microwave

Ablation and Portal vein ligation for

Staged hepatectomy

p-ALPPS - Partial ALPPS

PVE - Portal Vein Embolization

PVL - Portal Vein Ligation

RALPP - Radio-frequency Assisted

Liver Partition with Portal vein ligation

TSH - Two-Stage Hepatectomy

Received: 10.04 .2017

Accepted: 5.05.2017

\section{Rezumat \\ Util de reținut: procedeul ALPPS - adoptarea unei noi tehnici chirurgicale}

Introducere: Rezecția hepatică reprezintă singurul tratament potențial curativ al tumorilor hepatice maligne primitive sau secundare. Cea mai amenințătoare complicație a hepatectomiilor extinse este insuficiența hepatică postoperatorie datorată volumului hepatic rezidual insuficient. Tehnica ALPPS (Associating Liver Partition and Portal vein ligation for Staged hepatectomy) creşte semnificativ rata rezecabilității tumorilor hepatice nerezecabile prin procedeele standard, ca urmare a inducerii unei hipertrofii mai importante într-un interval de timp mai scurt, scăzând astfel riscul insuficienței hepatice postoperatorii.

Scop: Prezentarea tehnicii clasice a procedeului ALPPS (trisecționectomia dreaptă) şi a variantelor sale care au fost elaborate pentru reducerea ratelor înalte ale morbidității şi mortalității postoperatorii (care au fost raportate în seriile inițiale). Tehnica: ALPPS implică doi timpi operatori. Primul constă în ligatura ramului drept portal şi partiția "in situ" a ficatului la nivelul planului intersecțional stâng ("in situ splitting"). Spre deosebire de hepatectomiile clasice, porțiunea de ficat tumoral va fi lăsată pe loc, fiind vascularizată numai de artera hepatică dreaptă. Canalul hepatic drept şi venele hepatice trebuie prezervate, rămânând intacte după primul timp operator. $\mathrm{Al}$ doilea timp operator implică rezecția porțiunii de ficat tumoral, prin secționarea arterei hepatice drepte, a canalului hepatic drept şi a venelor hepatice eferente ale acestuia. De obicei, al doilea timp operator se desfăşoară la 7-15 zile de la prima operație.

Concluzii: ALPPS este un procedeu chirurgical adresat tumorilor 
hepatice nerezecabile prin hepatectomiile clasice (chiar şi după ligatura sau embolizarea ramului drept portal). Printr-o selecție atentă a pacienților şi printr-o tehnică minuțioasă adaptată fiecărui caz, au fost înregistrate rezultate postoperatorii superioare celor raportate inițial, ceea ce a condus la practicarea pe scară tot mai largă a acestui procedeu.

Cuvinte cheie: ALPPS, metastaze hepatice colorectale, ligatura ramului drept portal, chirurgie hepatică, tumori hepatice nerezecabile

\section{Abstract}

Background: Hepatic resection is the only potentially curative treatment for primary liver tumors and hepatic metastases. The most frightening postoperative complication of extensive hepatectomies is liver failure due to insufficient future liver remnant (FLR). The ALPPS technique (Associating Liver Partition and Portal vein Ligation for Staged hepatectomy) effectively increased the resectability of otherwise inoperable liver tumors (primary or secondary malignant liver tumor) by achieving a rapid and an effective hypertrophy of the FLR, which lowers postoperative liver failure risk.

Aim: To present the ALPPS classic right trisectionectomy and its technical variants which were invented to decrease the high rate of post-operative morbidity and mortality, reported in early case series.

Technique:ALPPS involves two stages. The first surgical procedure consists in the ligation of the right portal branch and the partition of the liver at the site of the falciform ligament (insitu splitting). In contrast to a classical hepatectomy, the tumoral hemiliver is left in situ and remains vascularized by the right hepatic artery only. The biliary and systemic venous drainages represented by the right biliary duct and respectively the hepatic veins, are preserved. The second step of the procedure is usually performed within 7 to 15 days after the firststage. The tumoral hemiliver is removed by sectioning the right hepatic artery, the biliary duct and the systemic venous pedicle.

Conclusions: The ALPPS technique is a therapeutic method for inoperable liver tumors by standard methods of hepatectomy \pm portal vein ligation (PVL). By careful patient selection and technical adjustment to the particular conditions of each case, better outcomes have been achieved, leading toan increasing number of surgeons who perform ALPPS.

Key words: ALPPS, colorectal liver metastases, portal vein ligation, liver surgery, unresectable liver tumors

\section{Introduction}

Hepatic resection is the curative treatment for liver malignancies, which are considered inoperable if FLR is insufficient - volumetric and functional. The limits of liver surgery were extended by improving the rate of FLR regeneration via portal vein ligation (PVL) or embolization (PVE). The first surgical technique that used portal flow modulation to hypertrophy the FLR, followed by hepatectomy within 6-41 days, was published in 1990 (1). Various variants of two-stage traditional hepatectomy (TSH) were described later, where portal vein occlusion was followed by hepatic resection, after 4-8 weeks (2). The most common causes for failure to complete surgical resection after PVL/PVL are inadequate hypertrophy of the FLR or local/systemic progression of cancer $(3,4)$.

The ALPPS technique was first published in 2012 and it is innovative by the fact that it associates PVL with ISS of hepatic parenchyma, thereby inducing an efficient and a rapid growth 
(7-10 days) of the FLR. This way both of the above mentioned disadvantages are diminished (5). The main advantage of ALPPS is that it can reduce the timeinterval between the two stages of the operation, thus diminishingthe risk of the disease progression. In addition, it allows for earlier assessment of abdominal cavity and liver quality. The pathophysiological mechanism of ALPPS remains unclear, but the effect is increased FLR hypertrophy. By dividing the hepatic parenchyma, the venous collaterals of the left and right hemilivers are interrupted, resultingin a more efficient redistribution of the portal flow, andsubsequently inducinga faster hypertrophy of the FLR. (Figs. 1,2,3,4)

In ALPPS, the FLR volume increase was

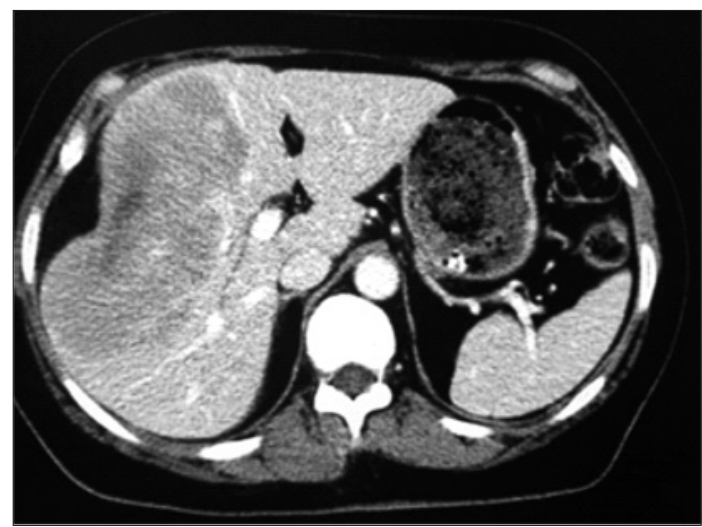

Figure 1. CT revealing a large liver tumor involving segments 4,5,6,8 (volume of segments 2-3: $295 \mathrm{cmc}, 13 \%$ of total liver volume) (13)

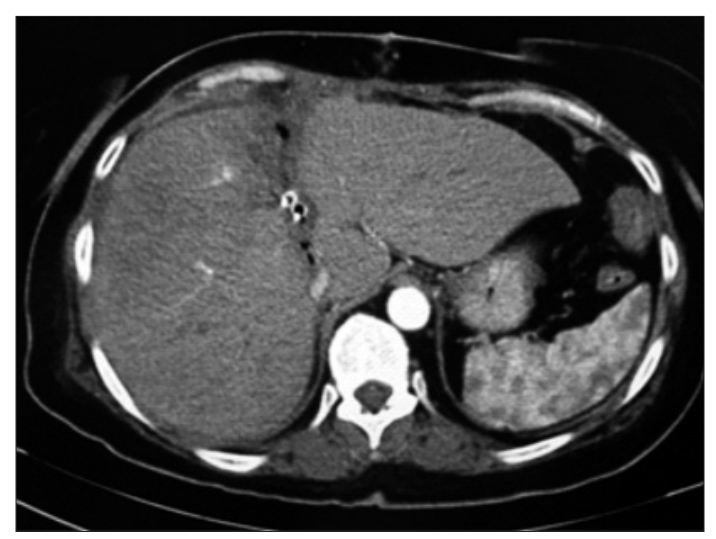

Figure 3. CT-scan performed at 11 days after right PVL and in-situ splitting (volume of segments 2-3: $586 \mathrm{cmc}, 27.3 \%$ of total liver volume) (13)
$14.4 \pm 4.8 \mathrm{~mL} / \mathrm{d}$ vs. $3.66 \pm 2.2 \mathrm{~mL} / \mathrm{d}$ in PVE, but from a functional point of view this difference is no longer so obvious. The histological changes of the FLR, detected by electronic microscopy are similar to those in the recovery of post-acute hepatitis (higher density of immature hepatocytes, glycogen accumulation, elevated Ki67) and are determined by hepatic congestion (a large flow of portal blood is routed into a small hepatic fragment) (6).

Initially the ALPPS technique was associated with a high rate of morbidity (68\% of patients experienced perioperative complications) and mortality (at 6 months after resection $12 \%$ of patients were dead) (5). These parameters were significantly improved by the modification of the

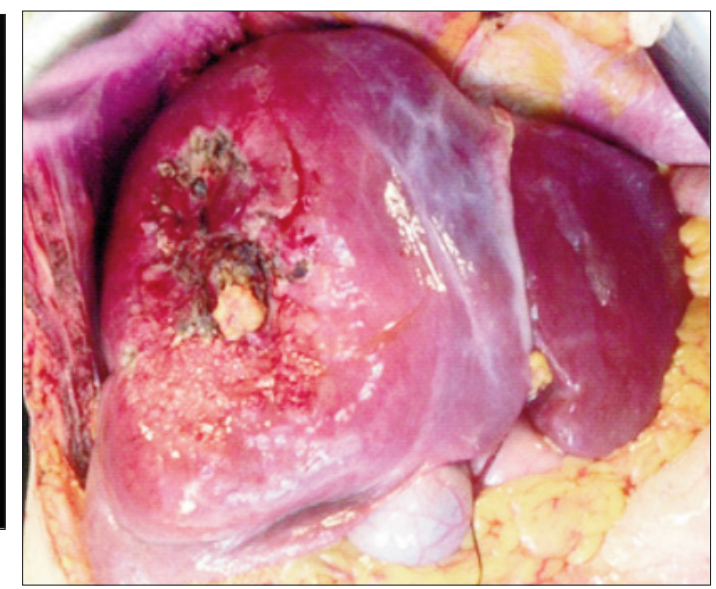

Figure 2. The intra-operative aspect

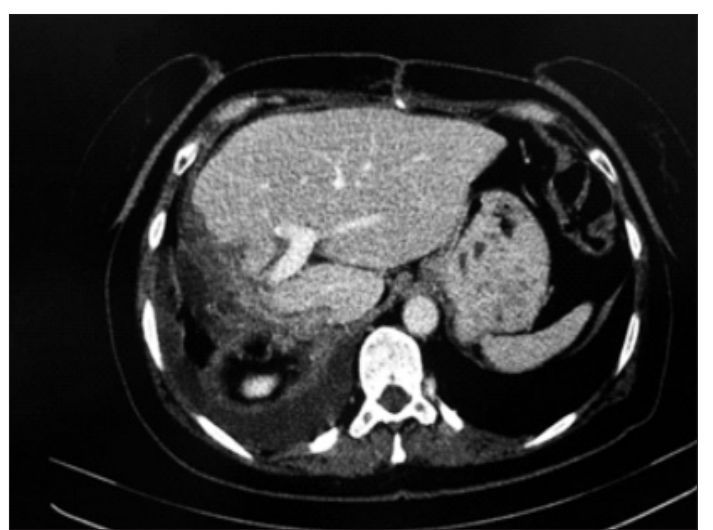

Figure 4. CT scan: final aspect after ALPPS 
initial technique, and the variants described being accepted by a growing number of surgeons. This demonstrates that ALPPS is a therapeutic solution for some of the liver tumors otherwise declared inoperable. According to the International ALPPS registry (2016) over 550 patients have benefited from this surgery, performed in over 84 centers worldwide (7).

\section{Indications}

An important role in the indication of the ALPPS procedure is played by the percentage of FLR, which is the ratio between the volume of FLR (mL) and total functional liver; the latter represents the difference between the total liver volume and the tumor volume (8). The ALPPSprocedure is reserved only for patients whose FLR is inadequate.

In the early years, due to associated risks, this technique was indicated only when FLR was up to $20 \%$ (of the normal liver parenchyma). Better results achieved in recent years by improving surgical techniques have increased confidence in this method and the indication has expanded to patients whose FLR was about $30 \%$. In patients with chemotherapyinduced liver injury or cirrhosis, it could also be applicable in patients with an estimated FLR of $40 \%(9)$.

In terms of diagnosis, the main indication for ALPPS is colorectal liver metastases (CRLM) and a small number of surgeons (16\%) consider this to be the only indication for ALPPS (10). A large number of CRLM patients benefited from neoadjuvant chemotherapy, but the response was not critical for the indication of ALPPS (both CRLMs that have had a favorable or partial response to chemotherapy and tumors that have progressed under treatment can be resected). The ALPPS procedure was also used as a new "liver- first" approach to treating CRLM (11).

The ALPPS technique is also applied in primary liver tumors. Hilar cholangiocarcinoma and gallbladder cancer are accepted by only $27 \%$ of surgeons as an indication for ALPPS because morbidity and mortality are higher than CRLM, especially when biliary reconstruction is needed
(10). The ALPPS procedure for hepatocellular carcinoma correlates with the degree of chronic liver damage, because in this context the liver regeneration is less predictable (12). Most surgeons (95\%) consider that Child Pugh Class $\mathrm{B}$ cirrhosis is an absolute contraindication to ALPPS, while in Child Pugh A cirrhotic patients, up to $18 \%$ surgeons would recommend this approach (10). Also, the primary hepatic lymphoma could be managed by ALPPS (13). This technique is contraindicated by presence of distant metastases (except potentially resectable lung metastases), the age higher than 75 years old, the advanced chronic liver disease (Fibrosis Metavir stage $\geq$ F3) and macrovesicular steatosis greater than 50\% (14).

\section{Technical consideration - Classic Right trisectionectomy ALPPS (Fig. 5)}

The surgical approach is through right subcostal incision or Mercedes Benz incision. Exploration of the peritoneal cavity aims at detecting extrahepatic lesions that would contraindicate surgery (with a radical oncological visa). The resectability of the tumor is subsequently assessed using intraoperative ultrasound, which allows both a complete balance of the lesions and their location and the relationship with the blood vessels. The small tumors in the left lateral lobe are resected. The liver is mobilized by cutting teres, falciform and triangular ligaments. The right hemiliver is

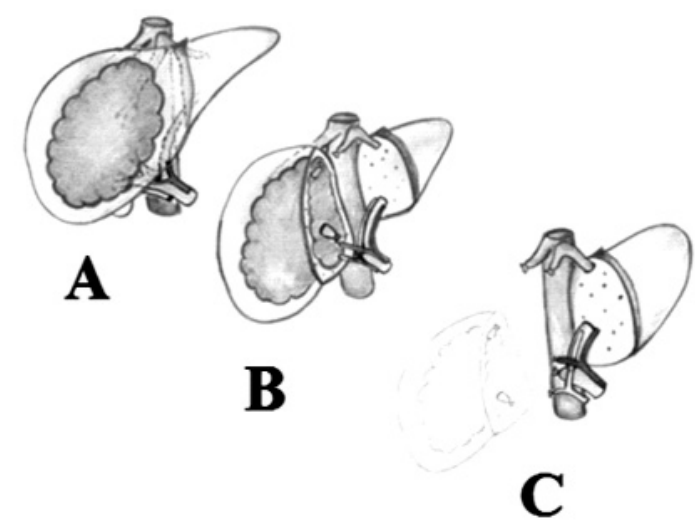

Figure 5. The ALPPS procedure (right trisectionectomy): A - Preoperative aspect. B - First stage. C - Second stage 


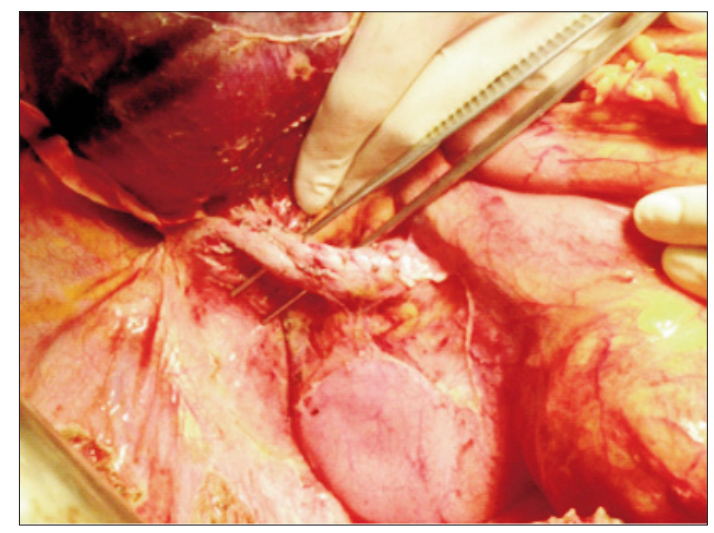

Figure 6. The dissection of inferior vena cava

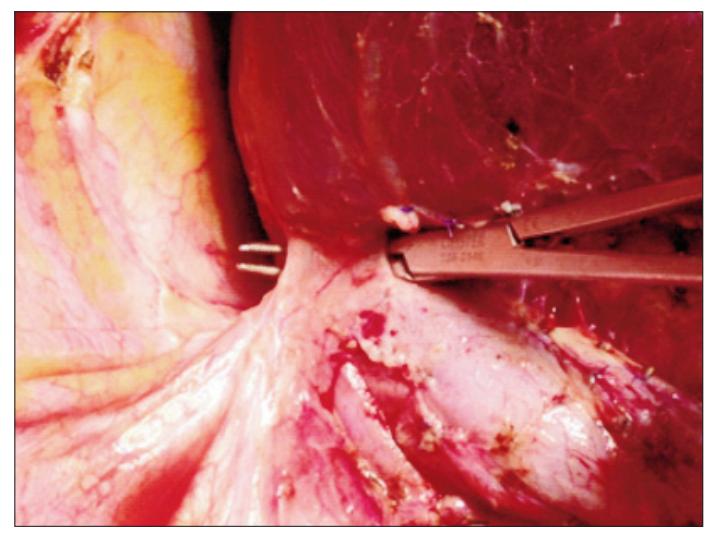

Figure 7. The dissection of right hepatic vein

released from the inferior vein cava by ligating and cutting the accessory liver veins (Fig. 6). Then the right hepatic vein is dissected and is placed on a vessel loop (Fig. 7). Routine colecistectomy is practiced, which is followed by the dissection of liver pedicle elements. The right branch of the portal vein is sectioned between ligatures (Fig. 8), and the right hepatic artery and right biliary duct are isolated and keptinto a vessel loop. If the bile duct for segment IV can be identified, it is added into the vessel loop. Finally, the total parenchymal dissection (Fig. 9) using the hanging maneuver plane (Fig. 10) at the right of the falciform ligament is performed using the various hepatic trans-

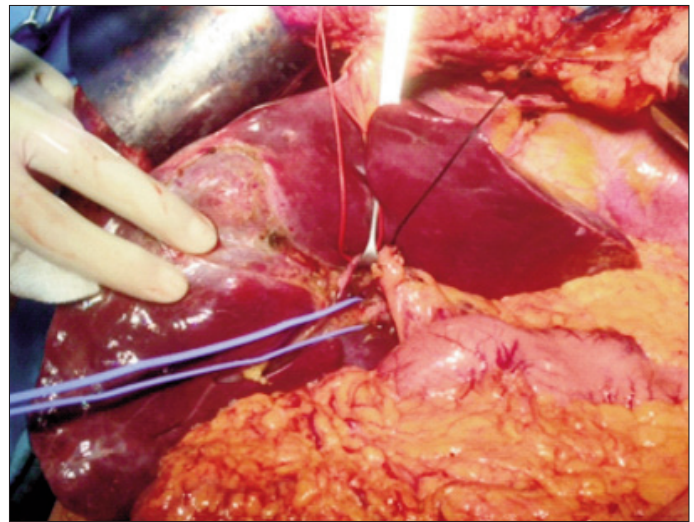

Figure 8. The dissection of right portal vein (13)

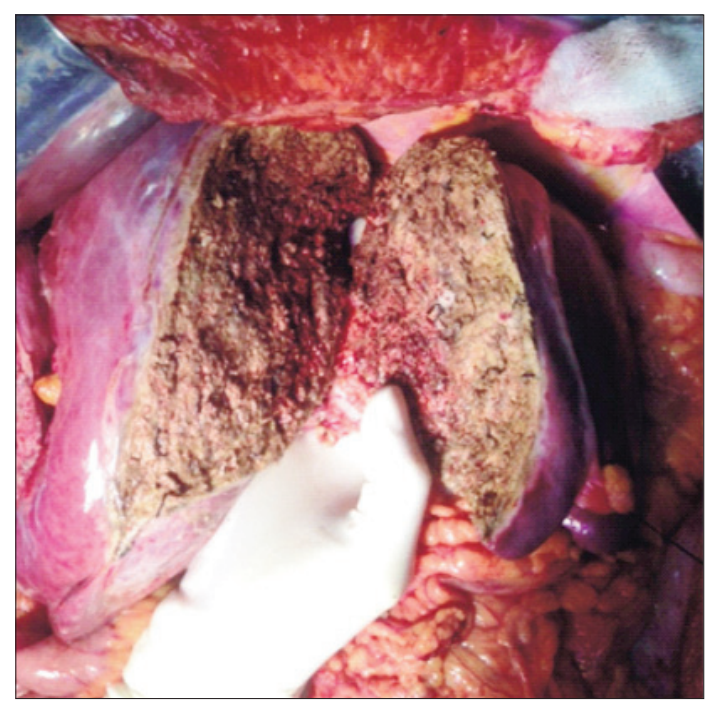

Figure 9. Complete transection of liver parenchyma

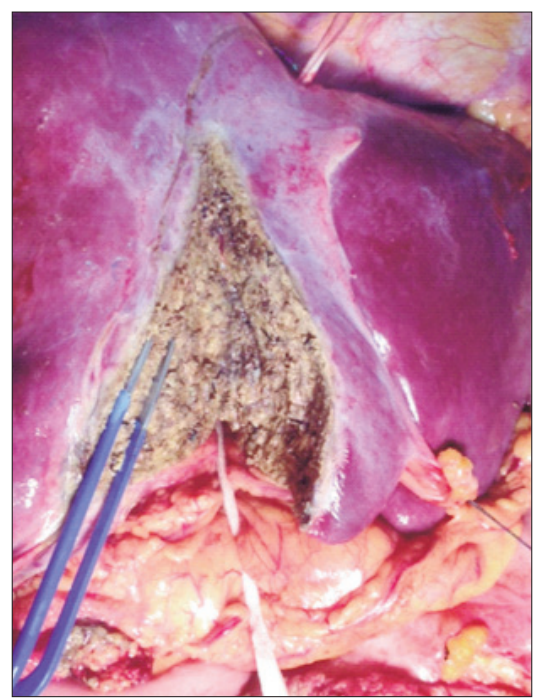

Figure 10. The hanging maneuver (in situ splitting) 
section techniques: kelly clamp and bipolar forceps, water jet dissection (Helix Hydro-jet, Erbe), ultrasonic dissection (Cavitron Ultrasonic Surgical Aspirator, Dissectron, Integra NeuroSciences), ultrasound dissection (Ultracision, EthiconEndo-Surgery) or dissecting sealer (TissueLink). After in situ splitting the right hemiliver including segment IV is covered by a biomaterial or a plastic bagto avoid adhesions prior the second stage and to collect the bile in case of bile leakage. Sometimes a Foley cathetercould be placed on the cut surface of the liverto avoid the development of the adhesions until the second operation (Fig. 11). The abdomen is drained and closed $(5,11)$.

Approximately one week (5-10 days) after PVL and parenchymal transsection, the increase in volume of FLR is checked by computer tomography and the second phase of ALPPS is decided (Fig. 12). A repeat laparotomy is performed and the plastic bag is removed. Then the surgeon cuts off the right hepatic artery, the right bile duct and the right and middle hepatic veins and removes the tumoral hemiliver. The left lateral lobe is then fixed to the residual falciform ligament to prevent its torsion around the left hepatic vein. Sometimes it may be necessary to reconstruct the bile ductby a Roux-en-Y hepaticojejunostomy. The peritoneal cavity is drained and the abdomen is closed.

This technique was initially associated with high perioperative morbidity, with $68 \%$ of patients presenting complications of varying degrees and a 90 -day mortality rate of $12 \%$ (5). To improve these results, the technique has been continuously refined and nowadays a large number of technical modifications of the ALPPS procedure are described.

\section{Non-touch Technique or "Hybrid ALPPS"}

Non-touch technique or "hybrid ALPPS" uses an anterior approach without the mobilization of right hemiliver and with the hepatoduodenal ligament left intact. Right PVE is performed by interventional radiology in the first few days following the operation, thus avoiding congestion and inflammation of the FLR $(15,16)$. Low

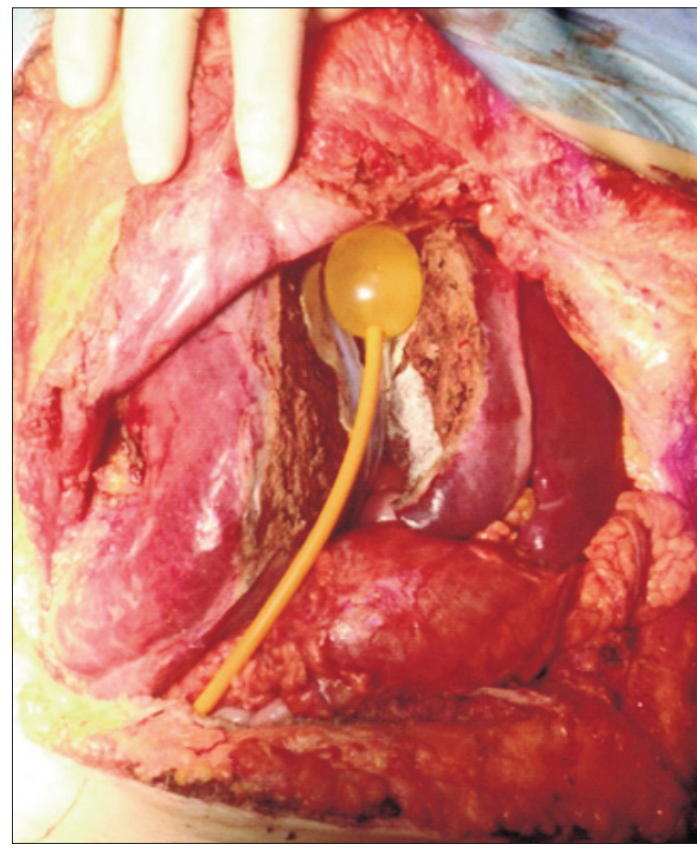

Figure 11. Placement of a Foley catheterto avoid the adhesions (13)

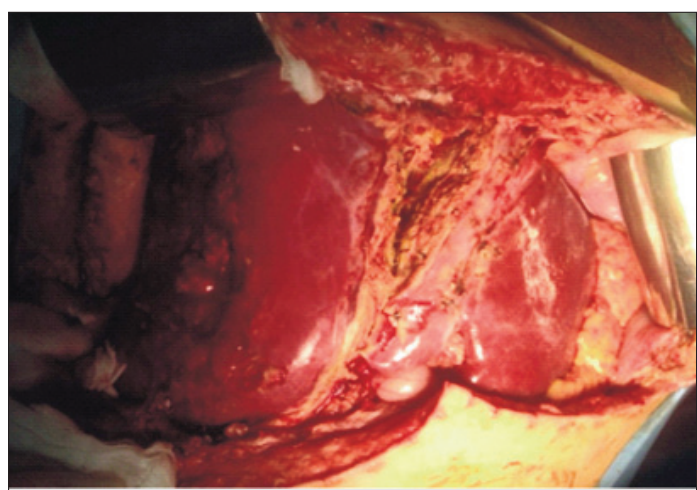

Figure 12. Second stage of the ALPPS

manipulation of tumoral hemiliver decreases, at least theoretically, the risk of oncological dissemination, but also reduces vascular control during hepatic parenchyma dissection (17).

The following three technical variants replace the classical transection of liver parenchyma with other methods aimed at interrupting the collaterals from the portal circulation between diseased hemiliver and FLR. These surgical procedures determine a hypertrophy of the FLR similar to the standard technique, but surgical complications are significantly reduced (no biliary fistula was detected, so the septic complication rate is significantly decreased). 


\section{Associating Liver Tourniquet and Portal Ligaton for Staged Hepatectomy - ALTPS}

This technique interrupts all collateral vessels between hemilivers (confirmed with intraoperative ultrasound) by using a tourniquet positioned around the liver following either Cantlie's line or the right of the umbilical fissure through a $1 \mathrm{~cm}$ deep groove in the parenchyma. The authors reported results similar to standard technique (hypertrophy of the FLR of $150 \%$ ), but the time and complexity of the intervention are lower, leading to an improvement in morbidity (18).

Sequential ALTPS is a variant of ALTPS in which the first stage consists of applying the tourniquet, without PVL. After 4 days postoperatively PVE is performed. It is indicated in perihilar tumors to allow a "nontouch" approach in order to reduce tumor spread. The delayed PVE may be related to a reduced impact and severity of venous congestion in the FLR (19).

\section{Radio-frequency Assisted Liver Partition with Portal Vein Ligation - RALPP}

After right PVL an in-line radiofrequency ablation (RFA) probe is applied to the parenchyma at the site of the demarcation (this producesa line of avascular necrosis along the future line of transection). This technique ceases blood flow from the FLR to the diseased hemiliver without a physical parenchymal split. No statistical difference was reported in a median 54\% increase in FLR in the RALPP group after a median of 20 days compared to a median increase in FLR of $67 \%$ after a median of 21 days. $(20,21)$

\section{Laparoscopic Microwave Ablation and Portal Vein Ligation for Staged Hepatectomy - LAPS}

The use of microwave ablation during the first stage through laparoscopic approach along the future plan of transection is associated with a $78 \%$ increase in FLR and a low number of complications (CD II - 1). On day 10, diseased hemiliver removal is easily accomplished due to reduced adhesions (22). Other authors also perform the second phase laparoscopically using Pfannenstiel incision to remove the hepatectomy piece (23).

\section{Partial ALPPS - p-ALPPS}

It involves only partial transection (between $50 \%-80 \%$ of the future transection plane) of the liver parenchyma during the first stage. The data indicate that $p$-ALPPS triggers rapid hypertrophy of the FLR, similar to ALPPS (60\% vs $61 \%$ median FLR hypertrophy), allowing a rapid completion of the 2-stage hepatectomy without severe postoperative complications (rate of severe complications CD $\geq \mathrm{IIIb} 0 \%$ vs $33 \%)$. The lower rate of complications can be explained by the decrease of segment ischemia, due to the partial maintenance of the vascularisation as the result of a smaller parenchymal split. $(24,25)$.

\section{Minimally Invasive Approach (Laparoscopic, Robotic)}

Was initially applied in the first stage of the ALPPS procedure, and was subsequently described exclusively in the laparoscopic ALPPS (26-28). Pneumoperitoneum reduces the systemic inflammatory response thus diminishing the chance of postoperative liver failure. Another way to reduce liver failure and therefore liver-related morbidity is to reduce liver ischemia by avoiding blood loss. Haemostasis during hepatic parenchymal dissection can be made by continuous selective clamping of the common hepatic artery, maintaining hepato-cellular function. After completion of liver partitioning, right portal vein is ligated (29).

\section{Segmental Modification}

Various modifications of ALPPS that alter the specific segments comprising the FLR have been described including left-sided ALPPS, segment 4 ALPPS and monosegmental ALPPS $(30,31)$. The ALPPS monosegment is the 


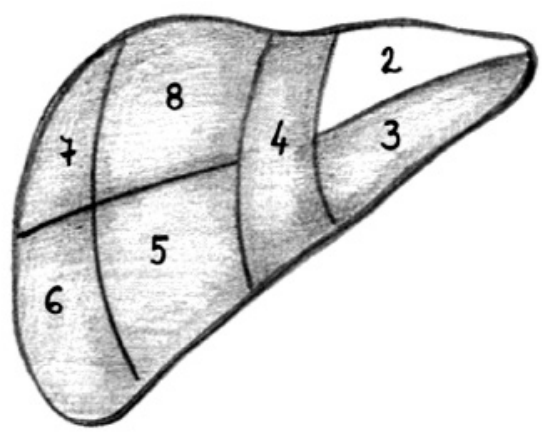

Figure 13. Segment 2 ALPPS (stipulate $\pm \mathrm{Sg} 1$ ) - resected Couinaud segments 3-8 $( \pm S g 1)$

technique by which 7 Couinaud segments are removed and the FLR being represented by one of the segments II, III, IV or VI (to which segment I may be added)(Fig. 13). (31)

Increased morbidity and mortality associated with the ALPPS procedure is often the consequence of complete devascularization of segment IV. Ischemic necrosis and infection (hepatic abscess, biliary fistula) can be prevented by various methods: the use of antibiotics between surgeries (32), the adoption of p-ALPPS which by partial parenchymal split preserves some of the segment IV vascularization, preserving the middle hepatic vein that prevents congestion of segment IV (33) and last but not least the resection of segment IV to avoid bile leak (34).

\section{Biliary Complications}

Biliary fistulae in the first stage of ALPPS can be identified by various methods (injection of methylene blue, Kabiven periferous or serum through the cystic duct). Intraoperative colangiography is generally reserved for the second stage. Some authors ligate the bile duct that serves the tumoral hemiliverin order to accelerate FLR hypertrophy, but thus increase by up to $88 \%$ the percentage of biliary complications (35). Ischemia of segment IV favors the development of biliary fistulas and bilomae - the management has been previously described. Some authors recommend the resection of segment I in the right trisectionectomy even if it did not have tumoral infiltration, in order to facilitate the bile ducts dissection during parenchyma transsection, thus lowering the rate of biliary complications (36). It is recommended to keep the hepatoduodenal ligament in order to avoid complete disruption of the vascularization of segment IV (33).

There are several methods of treating hepatectomy transits in the first stage of ALPPS to reduce adhesions and to facilitate the removal of liver tumor in stage 2. Frequently, a plastic bag is used in which the diseased hemiliver is introduced, which can collect the bile in case of a biliary fistula. It is possible to use a plastic sheath between the transection surface. Both methods require a reintervention to suppress them if FLR hypertrophy is not optimal and the removal of the tumoral hemiliveris not completed. This disadvantage is solved by: using a Foley catheter (13), omentoplasty (37), applying fibrin glue to the transection surface, using acellular collagen membranes or argon beam coagulation.

\section{Outcome}

Initially, the ALPPS technique was associated with a morbidity (CD > III) of $44 \%$ and mortality as high as $12 \%$ (5). The improvement of the technique and the careful selection of patients have led in the last years to a significant improvement of mortality at 90 days 8.8-9\%, CD > IIIb 27\% (26,38,39). Independent factors for severe complications were red blood cell transfusion, duration of stage I surgery greater than 300 minutes, age more than 60 years and non-colorectal liver metastases (hepatocellular carcinoma develops in patients with cirrhosis, gallbladder cancer or cholangiocarcinoma which requires biliary reconstruction). Patients with CRLM at the age of 60 years and younger had a severe complication rate of $16 \%$ and a 90 -days mortality of $5.1 \%(10,39)$.

The predominant cause for 90-day mortality was postoperative liver failure in $75 \%$ of patients and $14 \%$ of patients developed liver failure according to ISGLS criteria already after first stage. MELD>10 before stage- 2 was a significantly high risk for 90-day mortality. Size of FLR before stage- 2 and time between stages were not predictive (38). 


\section{Long-term Oncologic Outcomes}

Overall survival, however, is at 6 months between 86 and $100 \%$, dropping to $59 \%$ at 2 years $(33,39)$. The main cause of the dramatic decrease in survival rate is the recurrence of neoplastic disease (both liver-specific and extrahepatic). In the larger series of patients from the ALPPS registry, in those undergoing ALPPS for CRLM, the first and second year disease-free survival is $59 \%$ and $41 \%$, respectively (39).

\section{Conclusions}

ALPPS is an innovative surgical technique, which permits to extend the indication of hepatectomyto liver tumors considered unresectable by other techniques due to the fact that the liver parenchyma is insufficient volumetric and functional. The novelty element of this technique is represented by the split between the venous collaterals placed between the tumoral liver and FLR, which, together with PVL result in a more efficient redistribution of the portal flow compared with the two-stage hepatectomy. The portal flow is a trigger for the liver hypertrophy and thus results in a rapid and efficient increase of FLR, decreasing the risk of postoperative liver failure. The high rate of FLR hypertrophy significantly reduces the time between the two stages (from 4-8 weeks to 6-14 days), decreasing the risk of local and distant pro- $^{-}$ gression of the malignant disease. Initially, the morbidity and mortality rates associated to this technique were high but modifications of ALPPS and a more careful patient selection have resulted in better outcomes and a growing number of surgeons accept and employ this technique.

\section{References}

1. Makuuchi M, Thai BL, Takayasu K, Takayama T, Kosuge T, Gunven $P$, et al. Preoperative portal embolization to increase safety of major hepatectomy for hilar bile duct carcinoma: a preliminary report. Surgery. 1990:107(5):521-7.

2. Jaeck D, Oussoultzoglou E, Rosso E, Greget M, Weber J-C, Bachellier P. A two-stage hepatectomy procedure combined with portal vein embolization to achieve curative resection for initially unresectable multiple and bilobar colorectal liver metastases. Ann Surg. 2004;240(6):1037-51.

3. Abulkhir A, Limongelli P, Healey AJ, Damrah 0, Tait P, Jackson J, et al. Preoperative portal vein embolization for major liver resection: a meta-analysis. Ann Surg. 2008:247(1):49-57.

4. Tsai S, Marques HP, De Jong MC, Mira P, Ribeiro V, Choti MA, et al. Two-stage strategy for patients with extensive bilateral colorectal liver metastases. HPB. 2010;12(4):262-9.

5. Schnitzbauer AA, Lang SA, Goessmann H, Nadalin S, Baumgart J, Farkas SA, et al. Right portal vein ligation combined with in situ splitting induces rapid left lateral liver lobe hypertrophy enabling 2staged extended right hepatic resection in small-for-size settings. Ann Surg. 2012;255(3):405-14.

6. Matsuo K, Murakami T, Kawaguchi D, Hiroshima Y, Koda K, Yamazaki K, et al. Histologic features after surgery associating liver partition and portal vein ligation for staged hepatectomy versus those after hepatectomy with portal vein embolization. Surgery. 2016;159(5):1289-98

7. Cai Y-L, Song P-P, Tang W, Cheng N-S. An updated systematic review of the evolution of ALPPS and evaluation of its advantages and disadvantages in accordance with current evidence. Medicine (Baltimore). 2016;95(24):e3941.

8. Schindl M, Redhead D, Fearon K, Garden O, Wigmore S. The value of residual liver volume as a predictor of hepatic dysfunction and infection after major liver resection. Gut. 2005;54(2):289-96.

9. Day RW, Conrad C, Vauthey J, Aloia TA. Evaluating surgeon attitudes towards the safety and efficacy of portal vein occlusion and associating liver partition and portal vein ligation: a report of the MALINSA survey. HPB. 2015;17(10):936-41.

10. Buac S, Schadde E, Schnitzbauer AA, Vogt K, Hernandez-Alejandro $R$. The many faces of ALPPS: surgical indications and techniques among surgeons collaborating in the international registry. HPB. 2016;18(5):442-8.

11. Petrou A, Moris D, Kountourakis P, Fard-Aghaie M, Neofytou K Felekouras E, et al. The ALPPS procedure as a novel "liver-first" approach in treating liver metastases of colon cancer: the first experience in Greek Cypriot area. World J Surg Oncol. 2016; 14(1):67.

12. Van Lienden K, Van Den Esschert J, De Graaf W, Bipat S, Lameris J, van Gulik T, et al. Portal vein embolization before liver resection: a systematic review. Cardiovasc Intervent Radiol. 2013;36(1): 25-34.

13. Alexandrescu S, Stoica L, Grigorie R, Tomescu D, Dobrea C, Popescu I, et al. Primary Hepatic Lymphoma Resected by ALPPS Procedure. J Transl Med Res. 2016;21(2):153-8.

14. Sun Z, Tang W, Sakamoto Y, Hasegawa K, Kokudo N. A systematic review and meta-analysis of feasibility, safety and efficacy of associating liver partition and portal vein ligation for staged hepatectomy (ALPPS) versus two-stage hepatectomy (TSH). Biosci Trends. 2015;9(5):284-8.

15. Vennarecci G, Sandri GBL, Ettorre GM. Performing the ALPPS procedure by anterior approach and liver hanging maneuver. Ann Surg. 2016;263(1):e11.

16. Chan AC, Pang R, Poon RT. Simplifying the ALPPS procedure by the anterior approach. Ann Surg. 2014;260(2):e3.

17. Li J, Kantas A, Ittrich H, Koops A, Achilles EG, Fischer L, et al. Avoid "All-Touch" by hybrid ALPPS to achieve oncological efficacy. Ann Surg. 2016;263(1):e6-7.

18. Campos RR, Paricio PP, Conesa AL, Brusadín R, López VL, Grino $\mathrm{PJ}$, et al. A new surgical technique for extended right hepatectomy: tourniquet in the umbilical fissure and right portal vein occlusion (ALTPS). Clinical case. Cir Esp Engl Ed. 2013;91(10):633-7.

19. Campos RR, Brusadin R, Conesa AL, Paricio PP. Staged liver resection for perihilar liver tumors using a tourniquet in the umbilical fissure and sequential portal vein embolization on the fourth postoperative day (a modified ALTPS). Cir Esp Engl Ed. 2014;92(10): 682-6.

20. Gall TM, Sodergren MH, Frampton AE, Fan R, Spalding DR, Habib NA, et al. Radio-frequency-assisted Liver Partition with Portal vein ligation 
(RALPP) for liver regeneration. Ann Surg. 2015;261(2): e45-6

21. Sodergren M, Lurje G, Edmondson M, Psica A, Malago M, Jiao L. Bi-institutional case-matched comparison of short-term clinical outcomes of radiofrequency-assisted liver partition and portal vein ligation (RALPP) and associating liver partition and portal vein ligation for staged hepatectomy (ALPPS). HPB. 2016;18:e703-4.

22. Gringeri E, Boetto R, D’Amico FE, Bassi D, Cillo U. Laparoscopic microwave ablation and portal vein ligation for staged hepatectomy (LAPS): a minimally invasive first-step approach. Ann Surg. 2015; 261(2):e42-3.

23. Cillo U, Gringeri E, Feltracco P, Bassi D, D’Amico FE, Polacco M, et al. Totally Laparoscopic Microwave Ablation and Portal Vein Ligation for Staged Hepatectomy. Ann Surg Oncol. 2015;22(8): 2787-8.

24. Alvarez FA, Ardiles V, Claria RS, Pekolj J, de Santibañes E. Associating liver partition and portal vein ligation for staged hepatectomy (ALPPS): tips and tricks. J Gastrointest Surg. 2013; 17(4): 814-21.

25. Petrowsky H, Györi G, de Oliveira M, Lesurtel M, Clavien P-A. Is partial-ALPPS safer than ALPPS? A single-center experience. Ann Surg. 2015;261(4):e90-2.

26. Vicente E, Quijano Y, Ielpo B, Fabra I. First ALPPS procedure using a total robotic approach. Surg Oncol. 2015;

27. Machado MAC, Makdissi FF, Surjan RC. Totally laparoscopic ALPPS is feasible and may be worthwhile. Ann Surg. 2012;256(3):e13.

28. Conrad C, Shivathirthan N, Camerlo A, Strauss C, Gayet B. Laparoscopic portal vein ligation with in situ liver split for failed portal vein embolization. Ann Surg. 2012;256(3):e14-5.

29. Surjan RC, Makdissi FF, Basseres T, Leite D, Charles LF, Bezerra $\mathrm{RO}$, et al. First totally laparoscopic ALPPS procedure with selective hepatic artery clamping: Case report of a new technique. Medicine (Baltimore). 2016;95(29):e4236.

30. de Santibañes M, Alvarez FA, Santos FR, Ardiles V, de Santibañes $\mathrm{E}$. The associating liver partition and portal vein ligation for staged hepatectomy approach using only segments I and IV as future liver remnant. J Am Coll Surg. 2014;219(2):e5-9.

31. Schadde E, Malagó M, Hernandez-Alejandro R, Li J, Abdalla E, Ardiles V, et al. Monosegment ALPPS hepatectomy: extending resectability by rapid hypertrophy. Surgery. 2015;157(4):676-89.

32. Herman P, Krüger J, Perini MV, Coelho FF, Cecconello I. High Mortality Rates After ALPPS: the Devil Is the Indication. J Gastrointest Cancer. 2015;46(2):190.

33. Hernandez-Alejandro R, Bertens KA, Pineda-Solis K, Croome KP. Can we improve the morbidity and mortality associated with the associating liver partition with portal vein ligation for staged hepatectomy (ALPPS) procedure in the management of colorectal liver metastases? Surgery. 2015;157(2):194-201.

34. Andriani OC. Long-term results with associating liver partition and portal vein ligation for staged hepatectomy (ALPPS). Ann Surg. 2012;256(3):e5.

35. Dokmak S, Belghiti J. Which limits to the "ALPPS" approach? Ann Surg. 2012;256(3):e6.

36. Knoefel W, Gabor I, Rehders A, Alexander A, Krausch M, Schulte am Esch J, et al. In situ liver transection with portal vein ligation for rapid growth of the future liver remnant in two-stage liver resection. Br J Surg. 2013;100(3):388-94.

37. Troja A, Khatib-Chahidi K, El-Sourani N, Antolovic D, Raab H-R. ALPPS and similar resection procedures in treating extensive hepatic metastases: our own experiences and critical discussion. Int J Surg. 2014;12(9):1020-2.

38. Schadde E, Raptis DA, Schnitzbauer AA, Ardiles V, Tschuor C, Lesurtel $M$, et al. Prediction of mortality after ALPPS stage-1: an analysis of 320 patients from the international ALPPS registry. Ann Surg. 2015;262(5):780-6.

39. Schadde E, Ardiles V, Robles-Campos R, Malago M, Machado M, Hernandez-Alejandro R, et al. Early survival and safety of ALPPS: first report of the International ALPPS Registry. Ann Surg. 2014; 260(5):829-38. 